\title{
СУТНІСТЬ ЕЛЕКТРОННОЇ ОСВІТИ
}

\author{
Ковальов Д. І., Волошин О. Ф.
}

\section{ВСТУП}

Освітні технології, визначені Асоціацією освітніх комунікацій та технологій, - це науково-дослідні та етичні практики сприяння процесу навчання та підвищення його продуктивності шляхом створення, використання та управління відповідними технологічними процесами та ресурсами.

Освітні технології стосуються як фізичних компонентів, так $\mathrm{i}$ навчальних теорій. Вони включають декілька областей - теорію навчання, комп'ютерне навчання, онлайн-навчання та мобільне навчання (із застосуванням мобільних технологій). Відповідно, існує кілька дискретних аспектів опису інтелектуального та технічного розвитку освітніх технологій:

- освітні технології в теорії та практиці освітніх підходів до навчання;

- освітні технології як технічні засоби та засоби масової інформації, які допомагають у передачі знань, а також їх розвитку та обміну;

- освітні технології для систем управління навчанням (LMS), такі як інструменти для студентів чи системи управління навчальними програмами, а також системи управління інформацією (ISMS);

- освітні технології як предмети курсу; такі курси можуть називатися «Комп'ютерні дослідження» або «Інформаційнокомунікаційні технології (ІКТ)».

Інструменти електронного навчання - це програмні засоби або онлайн-сервіси, які дозволяють користувачам створювати курси, симуляції та інші освітні ресурси. Ці інструменти, як правило, підтримують традиційні презентаційні курси, а також можуть включати записи на екрані, мультимедійні файли, інтерактивне прослуховування та тестування, нелінійний або адаптивний підходи.

\section{1. Історія розвитку електронної освіти}

Оскільки походження слова e-learning не визначено, пропонується, що цей термін, імовірно, виник у 1980 -х роках ${ }^{1}$. Основна плутанина

${ }^{1}$ Moore J.L., Dickson-Deane C., \& Galyen, K. (2011). e-Learning, online learning, and distance learning environments: Are they the same? ScienceDirect, 1-4. 
дискурсу щодо електронного навчання - це його розмивання 3 дистанційного освітою: електронне навчання та дистанційна освіта не $є$ синонімами. Дистанційну освіту можна простежити до найдавніших часів, тоді як електронне навчання $\epsilon$ відносно новим явищем, пов'язаним з розвитком Інтернету в 90-х роках. Однак, безперечно, джерела електронного навчання лежать у дистанційній освіті та поділяють їі ідеї, що використання засобів масової інформації для можливості підтримувати масове навчання без взаємодії віч-на-віч. Еволюція дистанційного навчання може бути описана як неузгоджений метод педагогіки, який використовує нетрадиційне, звичайне та нове комунікаційне середовище для доставки інструктивних матеріалів без будь-яких географічних обмежень ${ }^{2}$.

Перший задокументований приклад навчання заочної форми навчання (коли як суто дистанційну освіту знали вже багато років) датується 1828 роком, коли професор К. Філіпс опублікував оголошення в Бостонському віснику, де пропонував навчальні матеріали та навчальні посібники заочно. У 1843 році було засновано Товариство фонографічної кореспонденції, що можна було би вважати першою офіційною установою з дистанційною освітою, що отримує, виправляє та повертає стенографічні вправи, виконані студентами, які проходять заочне навчання ${ }^{3}$.

Ідея про те, що такі технології, як радіо та телебачення, можуть бути використані для впровадження освіти для широкої аудиторії, почала циркулювати ще з 1920-х рр. у вигляді концепції «навчальних машин» Сідні Пресі. Пізніше, в 1950-х роках це було широко популяризовано творами Б. Е. Скіннера, але це не було актуальним аж до початку 1960-х років, лише тоді ця ідея набрала обертів, зі знаменним створенням відкритого університету в Великобританії, з маніфестним зобов'язанням у 1966 році, який став реальністю в 1971 році, коли цей університет почав приймати своїх перших студентів.

Приблизно з 1980 року почалася ера персональних комп'ютерів, що проклало шлях до електронного навчання. За останні 50 років на практиці було застосовано ряд нових підходів для сприяння ролі інструктора в класі ${ }^{4}$.

${ }^{2}$ Gros B., \& García-Peñalvo F. J. (2016). Future trends in the design strategies and technological affordances of e-learning. In M. Spector B.B. Lockee \& M.D. Childress (Eds.), Learning, Design, and Technology. An International Compendium of Theory, Research, Practice, and Policy (pp. 1-23). Switzerland: Springer International Publishing. doi:10.1007/978-3-319-17727-4_67-1

${ }^{3}$ Sangra, A., Vlachopoulos, D., \& Cabrera N. (2012). Building an Inclusive Definition of E-Learning: An Approach to the Conceptual Framework. IRRODL.

${ }^{4}$ Horton W. K. (2001). Leading E-Learning. Alexandria, VA: ASTD. 
Комп'ютерне базове навчання (СВТ) - це метод навчання, за якого первинна передача даних відбувається до комп'ютеру через програмне забезпечення через Інтернет або інтранет 5 . У 1960-х роках комп'ютерні інструкції прогресували у вивченні комп'ютерних баз. Комп'ютерне навчання використовувалося не лише для навчання, але й для спілкування. Піонерська система навчання на базі комп'ютеру - PLATO (програмована логіка для автоматичної навчальної операції) - почалася в 1960 році. Вона мала основний макет, який використовується в сучасному методі електронного навчання, що включає графічні елементи, текст разом із графікою, форуми та чати ${ }^{6}$.

Мультимедійні моделі навчання створили ряд ідеологій та вказівок для спрощення проектування навчання на базі комп’ютерів (ТБО). За допомогою комп'ютерного навчання практичне навчання можна зробити більш оперативним, де співвідношення студент-викладач один до одного і там, де навчання базується на семінарі або на основі роботи ${ }^{7}$.

На початку 90-х навчання на базі компакт-дисків розглядалося як нова технологія навчання електронного навчання. Іноді стали проводитися семінари в рамках навчання на основі компакт-дисків. Більше 95\% вмісту становлять уроки інформаційних технологій. Публічні дошки для чатів були створені на веб-сайтах, і це стало називатися «наставництвом».

Близько 1998 року Інтернет взяв на себе навчання на базі компактдисків, не лише надаючи навчальні інструкції та матеріали Інтернету, а також надаючи «персоналізований» досвід навчання за допомогою чатів, навчальних груп, інформаційні бюлетені та інтерактивний контент ${ }^{8}$.

На рис. 1 показані ключові технологічні розробки, що з'явилися за останні тридцять років, починаючи 3 інструментів для створення мультимедійних файлів, таких як Tookbook та Authorware наприкінці вісімдесятих, що дозволило користувачам створювати багаті та інтерактивні мультимедійні ресурси. Інтернет з'явився в 1993 році й спочатку був дуже статичним інтерфейсом, не міг обробляти велику

5 Rouse M. (2011, March). computer-based training (CBT). URL: www.whatis.techtarget.com/:http://whatis.techtarget.com/definition/computer-basedtraining-CBT

${ }^{6}$ Shimura K. (2006). Computer-based learning and web-based training: A review for Computer-based learning and web-based training: A review for. 59-63.

${ }^{7}$ Dean C., \& Whitlock Q. (1992). A handbook of computer-based training. Based Training. New York, NY: Nichols Publishing Company.

${ }^{8}$ Cross J. (2004). An informal history of eLearning. Emerald, 1-8. 
кількість зображень або мультимедіа через погану пропускну здатність. У середині дев'яностих практики почали говорити про поняття предметів навчання і прагнення створювати та ділитися навчальними матеріалами на яскравому ринку освіти.

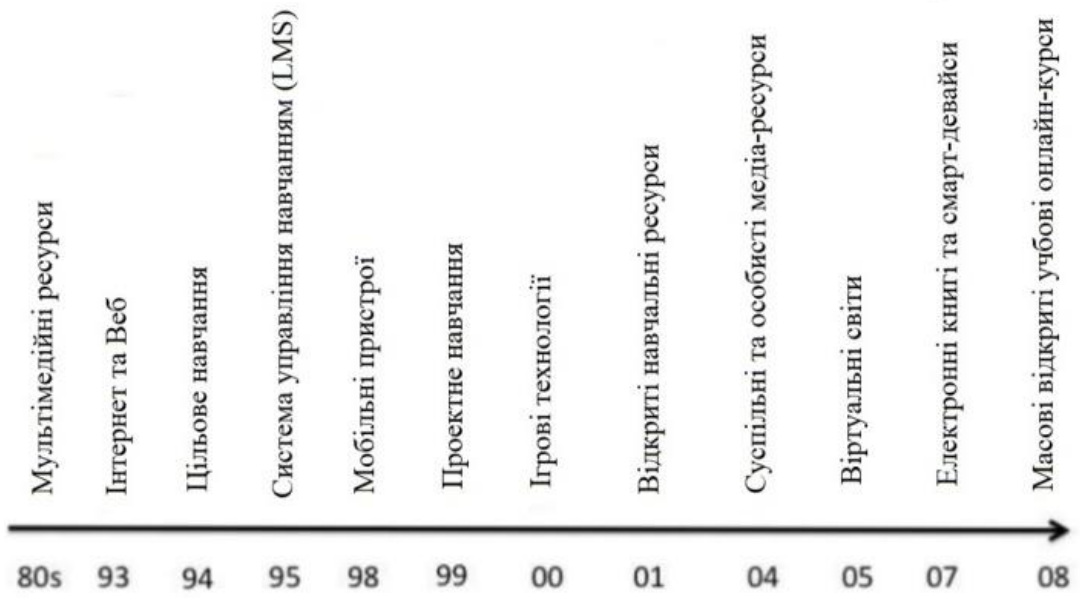

Рис. 1. Часова шкала розвитку e-learning9

Коли Інтернет та персональні комп'ютери набули досконаліших характеристик та почали процвітати наприкінці 20 -х століття, тоді й поняття електронного навчання почало набувати форми. Технологія, концепція та пристрої добре доповнювали одне одного, забезпечуючи нову тенденцію навчання. Перша веб-керувальна навчанням система (LMS) на ім'я Сесіль була запущена в 1996 році10. LMS - це програмне забезпечення, яке організовує, документує, записує та проводить курси електронного навчання. Сучасні LMS переважно базуються на вебдоступних засобах або доставці різних типів навчального контенту, включаючи, але не обмежуючись таким, як: літературні матеріали, відео та аудіо, вікі, веб-конференції, чати, форуми, блоги, навчальні ігри, тестування, оцінювання тощо.

${ }^{9}$ Moore J. L., Dickson-Deane C., \& Galyen K. (2011). e-Learning, online learning, and distance learning environments: Are they the same? ScienceDirect, 1-4.

${ }^{10}$ Sheridan D., Gardner L. \& White, D. Cecil: The first web-based LMS. Proceedings of ASCILITE Auckland 2002. 


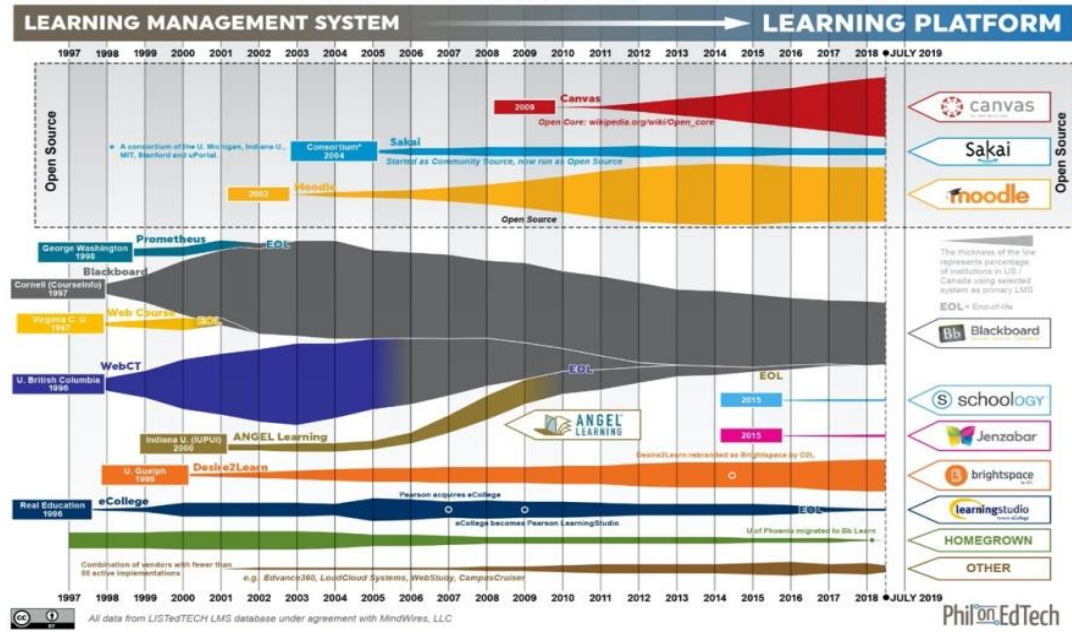

Рис. 2. Часова діаграма розвитку різних LMS на ринку надання учбових послуг для США та Канади ${ }^{11}$

Система управління навчанням (LMS), яку також називають системою управління курсами (CMS), або віртуальне навчальне середовище (VLE) еволюціонували десятиріччями. Технології інновації стануть наріжним каменем інфраструктури навчальних технологій. LMS була популяризована 3 появою Інтернет, сьогодні існує багато платформ LMS. LMS-платформи, як правило, включають набір інтегрованих інструментів, які дають змогу в Інтернеті здійснювати доставку навчального контенту, взаємодію, співпрацю і відстеження 3 утворенням звітності про участь студентів (Rouse, 2005).

Останні дослідження студентів вищих навчальних закладів та їхні технологічні уподобання зазначили, що майже всі студенти використовують LMS, i що LMS послідовно ідентифікується студентами як серед більшості важливих навчальних технологій для іхнього академічного успіху ${ }^{12}$.

LMS залишається основою Інтернет-інфраструктури освіти, 85\% викладачів підтверджують використання ними LMS установи, 81\% керівників в Інтернеті - працівники освіти, які повідомляють,

${ }^{11}$ https://eliterate.us/state-higher-ed-lms-market-us-canada-fall-2017-edition/

12 Brooks D. C. (2015). ECAR study of faculty and information technology, 2016. Research report. Louisville, CO: ECAR. URL: https://library.educause.edu/resources/ 2015/8/2015-student-and-faculty-technologyresearch-studies 
що LMS $є$ найважливішою технологією в Інтернет-програмах ${ }^{13}$. Лідери інституцій визнають важливість підтримки викладачів у використанні навчальних технологій, включаючи LMS, що з розвитком факультету займає перше місце як ключове питання у навчанні.

Подальшим важливим кроком у розвитку електронної освіти $\epsilon$ використання мобільних пристроїв (m-learning). Перше покоління мобільних пристроїв з'явилося близько 1998 року, хоча вони мали дуже обмежені можливості, й важко було зрозуміти, що вони можуть запропонувати для навчання. Дизайн навчання як дослідницьке поле виник як протидія довгому створенню поля інструктивного проектування. Основна увага приділялася створенню інструментів та ресурсів, щоб допомогти практикуючим людям приймати більш обгрунтовані розробницькі рішення.

Марк Пронський у 2001 р. написав у своїй книзі «Навчання цифровим іграм» про еволюцію ігрових технологій (gamification) та про те, як змінилися учні через роки гри. Усе почалася зі згадування найпершої комерційної відеоігри під назвою «Понг», що з'явилася у 1974 р. Багато дітей у цей час спостерігали за вулицею Сезам як щоденною частиною їнього інтелектуального життя. Вулиця Кунжутна привернула їхню увагу, оскільки вона навчала їх день у день і з року в рік. У книзі «Переломний пункт» Малкольм Гладвелл пише: «Якщо ти можеш привернути увагу дітей, ти можеш їх виховати». Звичайно, їм було весело дивитися таку програму. Цей зв'язок між розвагою та навчанням був частиною половини цього покоління. Космічні окупанти та Зоряна війна були першими відеоіграми, які особливо слідували після фільму, який був показаний з тою самою назвою. Це була «Джойстік-нація», як писав Дж. Герц у своїй «Книзі».

У 1990 році комп'ютери почали надходити до аудиторії, а також вдосконалили новіші методи ігрових технологій. Ігри, наприклад Маth Blaster, були введені дітям у той час із великим ефектом, але їх критикували, що ці ігри занадто складно пов'язати 3 навчальною програмою, і вони занадто зосереджені на практиці повторювання невеликого набору навичок, таких як додавання та віднімання ${ }^{14}$. Це був 2002 рік, коли ініціатива «Серйозні ігри» відігравала велику роль в організації та прискоренні прийняття комп'ютерних ігор для різноманітних викликів, що стоять перед світом. Було запропоновано

13 Legon R., \& Garrett R. (2017). The changing landscape of online education (CHLOE): Quality Matters and Eduventures survey of chief online officers, 2017. URL: https://www.qualitymatters.org/node/1040

14 Youssef Y. Gamification in e-learning//2015 https://www.researchgate.net/ publication/301202645 
близько 2000 ігрових технологій, зокрема тих, як ігри можна використовувати в навчальному контексті.

Віртуальні світи, такі як Secondlife, набули популярності приблизно в 2005 році; багато хто вважав, що вони пропонують занурюючі та автентичні тривимірні середовища, які можуть сприяти таким педагогікам, як рольова гра, проблемне навчання та розташоване навчання. Після цього наслідувало друге покоління мобільних пристроїв, зокрема електронні книги, планшети та смартфони. Це зробило мантру «навчання в будь-якому місці та в будь-який час» реальністю. Нарешті, наступним етапом у континуумі навчальних об'єктів відкритих освітніх ресурсів (OER) стала поява масових відкритих онлайн-курсів (МООС), до яких підписалися тисячі людей. Зараз розвинулися два типи МООС:

1) сМООС, що сприяють кон'юнктивістському навчанню (Siemens 2005);

2) хМООС, які є більш лінійними та дидактичними, як, наприклад, запропоновані Coursera.

Мільйони зареєстрованих користувачів MOOCs пропонують сотні курсів по всьому світу. MOOCs часто випускаються сторонніми онлайн-платформами та розробляються незалежними науковцями. Історія MOOCs не дуже стара. Термін уперше впроваджено у 2008 році Стівеном Доуном i Джорджем Сіменсом i засновано на «кон'юнктивістській» моделі розподіленого однорічного навчання. Слідом за ним у 2011 році ще кілька освітніх відеороликів були розроблені професорами зі Стенфордського університету та випущені через відкриті онлайн-платформи, що підтримуються безкоштовними веб-ресурсами. Цього ж року МООС вибухали по всьому світу; кількість їх досі розширюється з кожним днем все більше. Пізніше, на початку 2012 року, встановили Coursera як незалежну комерційну технологію. Того ж року відбулися інші незалежні некомерційні ініціативи, такі як Udacity та Udemi. Після цього Массачусетс та Гарвард включили свою платформу MITx до EdX. За ними слідували інші платформи Futurelearn та Iversity, які не $\epsilon$ американськими платформами США, а європейськими. Вони доставляють їхні курси по всій Свропі. Futurelearn належить Відкритому університету Великобританії, це відоме ім'я в галузі дистанційної освіти 3 великим педагогічним досвідом та досвідом. Iversity - німецька ініціатива, засновники якої пишаються тим, що змогли скористатись Європейською системою кредитних переказів. Вони заявляють, що їхні партнерські заклади мають можливість запропонувати іспити, які надають бали за ECTS. Будучи єдиною платформою, МООС-курси, 
які пропонують кредити ECTS, працюють над розширенням цієї можливості ${ }^{15}$.

\section{2. Сучасна класифікація електронної освіти}

Люди дуже часто користуються такою пошуковою системою, як Google, щоб шукати інформацію, починаючи від того, що їсти, до того, що носити в конкретний день. Люди консультуються з різних блогів чи онлайн-підручників, щоб дізнатися про продукти чи конкретні способи виконання завдань.

Все це - процеси електронного навчання. Залежно від використання джерела або засобу надання послуг електронне навчання може бути різного типу ${ }^{16}$ :

- чисто в Інтернеті: ніяких зустрічей віч-на-віч;

- змішане навчання: дистанційне навчання або комбінація онлайн та віч-на-віч;

- синхронне: онлайн-курси, які ведуть інструктори;

- асинхронне: самостійні методи навчання, розміщені в Інтернеті, мережі чи пристрої зберігання даних;

- група під керівництвом інструкторів: дистанційне навчання, де студенти можуть бути різними за географічним розташуванням, але вчитися в одного вчителя;

- самостійне навчання: навчання за допомогою відвідування блогів, навчальних посібників чи інформаційних веб-сайтів;

- самостійне навчання 3 експертом із предметів: навчання шляхом регулярного відвідування деяких експертних блогів або сучасних сайтів;

- веб-базування: навчання виключно за допомогою пошуку в Інтернеті 3 використанням пошукових движків або групи соціальних медіа, таких як Facebook;

- комп'ютерні: навчання через доступ до навчальних матеріалів 3 різних сховищ таких пристроїв, як CD ROM або USB в комп'ютері;

- відео/аудіокасета: навчання за допомогою доступу до мультимедійних файлів через YouTube або будь-які інші веб-сайти для обміну відео/аудіо [6].

Залежно від використання технологічного прогресу та інтерактивних можливостей системи навчання електронне навчання можна розділити на три різні типи, як показано в таблиці.

${ }^{15}$ Meltem Huri Baturay. An overview of the world of MOOCs. Procedia - Social and Behavioral Sciences 174 (2015 ). P. 427-433.

16 Guragain N. E-Learning Benefits and Applications - Helsinki Metropolia University of Applied Sciences, Bachelor of Engineering//Information Technology. Thesis / February 2016 https://core.ac.uk/download/pdf/38134334.pdf 


\section{Типи електронного навчання на основі їхніх інтерактивних можливостей ${ }^{17}$}

\begin{tabular}{|c|c|c|}
\hline Тип 1 & Тип 2 & Тип 3 \\
\hline $\begin{array}{l}\text { Системи електронного } \\
\text { навчання з низькими } \\
\text { інтерактивними } \\
\text { можливостями, які } \\
\text { складаються } \\
\text { переважно з текстів або } \\
\text { мультимедійних } \\
\text { матеріалів. }\end{array}$ & $\begin{array}{l}\text { Системи електронного } \\
\text { навчання } 3 \text { помірними } \\
\text { інтерактивними } \\
\text { можливостями. }\end{array}$ & $\begin{array}{l}\text { Системи електронного } \\
\text { навчання з високими } \\
\text { інтерактивними } \\
\text { можливостями або } \\
\text { студент зі студентом, } \\
\text { або студент } 3 \\
\text { викладачем, або навіть } \\
\text { обидва варіанти. }\end{array}$ \\
\hline $\begin{array}{l}\text { Приклади цього типу: } \\
\text { системи переважно } \\
\text { складаються } 3 \\
\text { презентацій Power } \\
\text { Рoint, навчання } 3 \\
\text { електронної книги або } \\
\text { навчання } 3 \text { переглядом } \\
\text { відео чи } \\
\text { прослуховуванням } \\
\text { аудіопідкасту. }\end{array}$ & $\begin{array}{l}\text { Приклади цього типу: } \\
\text { системи, що переважно } \\
\text { складаються з вікторин } \\
\text { із відгуками, } \\
\text { інтерактивні ресурси, } \\
\text { рефлексивне навчання } \\
\text { та навчання за } \\
\text { допомогою тренажерів } \\
\text { або демонстрації. }\end{array}$ & $\begin{array}{l}\text { Приклади цього типу: } \\
\text { системи переважно } \\
\text { складаються } \\
\text { або сучасні змішані } \\
\text { системи для } \\
\text { впорядкування, такі як } \\
\text { віртуальні аудиторії, } \\
\text { відеоконференції, } \\
\text { потокове передавання } \\
\text { медіа, різні Інтернет- } \\
\text { групові ігри, онлайн- } \\
\text { блоги, Вікіпедія або } \\
\text { соціальні медіагрупи }\end{array}$ \\
\hline
\end{tabular}

Електронне навчання має багато переваг. За допомогою поєднання добре організованої системи електронного навчання i високомотивованого студента можна досягти великих успіхів за короткий проміжок часу. Нижче наведено деякі основні переваги електронного навчання:

a) зручний для студентів;

Матеріали електронного навчання розміщуються самостійно, й до них може отримати доступ будь-хто. Вони не вимагають від учня фізичної присутності в класі.

Студенти також можуть завантажувати та зберігати навчальні матеріали для майбутніх цілей від системи.

б) низька вартість;

Електронне навчання зазвичай $є$ економічно ефективним способом навчання для більшості студентів, оскільки можна вибрати з великого спектру курсів і зробити вибір залежно від особистої потреби. Це також

${ }^{17}$ E-learning Essentials, WorldWideLearn. URL: http://www.worldwidelearn.com/ elearning-essentials/elearning-types.htm Accessed 9th December 2015. 
може бути рентабельним для багатьох університетів, оскільки колись створені навчальні платформи можна повторно використовувати протягом багатьох сесій.

в) сучасні навчальні матеріали;

Навчальні матеріали в системах електронного навчання можна оновлювати частіше, ніж у системах навчання на основі класу. Як тільки навчальні матеріали розміщені в системі, вони можуть бути оновлені без зміни цілих матеріалів, а матеріали можуть бути доступні та використані довше.

г) гнучкий спосіб навчання;

Електронне навчання - це гнучкий спосіб навчання для багатьох студентів. Більшість навчальних матеріалів зберігаються для доступу студентів, коли вони хочуть. Студенти можуть також вибирати між системою, що керується викладачами та системою самонавчання. В електронному навчанні система також дозволяє студентам пропускати навчальні матеріали, які вони вже знають, і вибирати ті, які вони хочуть вивчити.

д) Всесвітне навчальне суспільство;

Системи електронного навчання допомагають створити всесвітнє навчальне суспільство, коли будь-хто може отримати доступ до навчальних матеріалів незалежно від географічного положення. У доступних зараз системах учні також можуть вносити свій внесок у навчальні матеріали, що допомагає постійно оновлювати матеріали ${ }^{18}$.

е) масштабовані системи електронного навчання;

Кількість студентів у віртуальних класах або системах електронного навчання може бути дуже малою або дійсно високою, не спричиняючи суттєвої різниці в загальній вартості.

є) вища ступінь свободи для студентів;

Можливо, не вистачає відведеного часу, щоб дізнатися нової ідеї. Системи електронного навчання забезпечують можливість студентам вивчати один і той же матеріал повторно, поки вони не стануть задоволені.

ж) краще збереження;

Відео- та аудіоматеріали, які використовуються в електронному навчанні, роблять увесь процес навчання більш приємним. Це допоможе учням запам'ятати те, чого вони навчаються тривалий проміжок часу. До матеріалів електронного навчання також можна отримати доступ, коли потрібно; таким чином, повторення полегшує утримання ${ }^{19}$.

18 Kuhlmann T. (2010) Why E-learning is so effective. URL: http://blogs.articulate.com/rapid-elearning/why-e-learning-is-so-effective/ Accessed 19th December 2015.

${ }^{19}$ Benefits of E-learning, WorldWideLearn. URL: http://www.worldwidelearn.com/ elearning-essentials/elearningbenefits.htm Accessed 19th December 2015. 
Як і в будь-яких інших системах електронного навчання, також $є$ деякі недоліки. Бути гнучким не завжди добре, оскільки це може спричинити лінь i, таким чином, знизити ефективність. До основних недоліків електронного навчання належать:

а) низька мотивація;

Учні з низькою мотивацією можуть не досягати поставлених цілей довгий час, оскільки нема кому переглядати. Студенти самі відповідають за розпорядок дня та організацію курсу, що призводить до ліні та низької мотивації дій. Відсутність фіксованого розкладу та термінів може призвести до передчасної відмови студентів від курсу.

б) технологічна залежність;

Навчальні матеріали в електронному навчанні подаються за допомогою комп'ютерних додатків. Для деяких людей просте навчання користуватися цими програмами може зайняти довгий період часу. $\mathcal{C}$ й інші фактори, такі як поганий зв'язок з Інтернетом та несправність машини, що може зробити процес навчання стомлюючим та тривалим у споживанні.

в) питання сумісності;

Оскільки існує багато систем навчання, іноді навчальні матеріали, підготовлені за допомогою однієї системи, можливо, не сумісні з іншою. Наприклад, мобільні пристрої, такі як iPad, блокують відтворення флешвідео їхніх браузерів. Доступ до веб-сайтів може бути безкоштовним не у всіх місцях, оскільки деякі країни встановлюють обмеження на кількість веб-сайтів, до яких можна отримати доступ.

г) надійність змісту;

Вміст, доступний в Інтернеті, не завжди може бути надійним. Існують люди, які вводять в оману читачів і подають неправильну інформацію. Тож, читачі повинні бути обережними під час пошуку інформації та перевірки достовірності змісту перед його вивченням.

д) соціальна ізоляція;

Відсутність справжньої аудиторії чи однокласників може бути не всім студентам до вподоби. Студенти можуть часом відчувати себе соціально ізольованими через брак реальних людей навколо себе під час навчання.

е) управління витратами;

Зрештою, електронне навчання - це зазвичай більш дешевий варіант, але все ж уперше може виявитися занадто кошторисним для деяких установ. Нове обладнання, таке як комп'ютери, проектори чи нове програмне забезпечення, відразу не завжди може бути простим для користування. Також висока вартість розробки навчальних матеріалів порівняно з традиційними методами.

є) недоліки для студентів-інвалідів;

Під час розробки нових навчальних матеріалів або навчальних середовищ компанії зазвичай націлювані на великі групи користувачів. 
Вони не завжди можуть думати про студентів з обмеженими фізичними можливостями, таких як студенти 3 вадами зору. Оскільки вони не можуть отримати від цього відшкодування, витрати на розробку можуть бути високими.

ж) неефективне в деяких випадках;

Іноді навчальні матеріали віч-на-віч можуть бути ефективнішими, ніж навчання в Інтернеті, оскільки електронному навчанню бракує двостороннього спілкування ${ }^{20,21}$.

У таблиці 2 нижче викладено деякі основні переваги та недоліки проходження електронного навчання.

Таблиця 2

\section{Переваги та недоліки систем електронного навчання}

\begin{tabular}{|l|l|}
\hline \multicolumn{1}{|c|}{ Переваги } & \multicolumn{1}{|c|}{ Недоліки } \\
\hline $\begin{array}{l}\text { Це зменшує необхідність подорожувати } \\
\text { отримати бажану освіту. }\end{array}$ & $\begin{array}{l}\text { Не вистачає взаємодії віч-на-віч, яку } \\
\text { мали б отримати студенти у } \\
\text { звичайній аудиторії. }\end{array}$ \\
\hline $\begin{array}{l}\text { Це зручний спосіб вивчення речей з } \\
\text { отриманням доступу в будь-якому місці } \\
\text { й на власний розсуд. }\end{array}$ & $\begin{array}{l}\text { Відсутність суворих рекомендацій } \\
\text { може призвести до демотивації } \\
\text { студенту та до передчасної відмови } \\
\text { від процесу навчання. }\end{array}$ \\
\hline $\begin{array}{l}\text { Це власна особиста система навчання, } \\
\text { досить гнучка для учнів. }\end{array}$ & $\begin{array}{l}\text { Іноді важко виміряти надійність } \\
\text { розміщених систем навчання. }\end{array}$ \\
\hline $\begin{array}{l}\text { Використання медіаресурсів робиться } \\
\text { таким чином, що учням це легко } \\
\text { зрозуміти. }\end{array}$ & $\begin{array}{l}\text { Повільне підключення до Інтернету } \\
\text { чи проблеми із сервером можуть } \\
\text { спричинити невдоволення від } \\
\text { навчального процесу. }\end{array}$ \\
\hline $\begin{array}{l}\text { Системи електронного навчання } \\
\text { забезпечують можливість студентам } \\
\text { вивчати один і той же матеріал повторно, } \\
\text { поки вони не стануть задоволені. }\end{array}$ & $\begin{array}{l}\text { Може знадобитися певний час } \\
\text { навчання лише для розуміння } \\
\text { навчальних систем. }\end{array}$ \\
\hline $\begin{array}{l}\text { Простіше відстежувати прогрес учнів у } \\
\text { системі електронного навчання. }\end{array}$ & $\begin{array}{l}\text { Студенти можуть відчувати себе } \\
\text { ізольованими через відсутність } \\
\text { соціальної взаємодії. }\end{array}$ \\
\hline $\begin{array}{l}\text { Зміст навчальних матеріалів } \\
\text { узгджується з усіма користувачами } \\
\text { незалежно від місця та часу доступу. }\end{array}$ & $\begin{array}{l}\text { Взаємодія в режимі реального часу } \\
\text { може бути недоступною тоді, } \\
\text { коли це потрібно студентам, } \\
\text { розчаровує їх. }\end{array}$ \\
\hline
\end{tabular}

20 Mobbs R. (2003). Disadvantages of E-learning, What is e-learning. URL: https://www.le.ac.uk/users/rjm1/etutor/elearning/disadvofelearning.html. Accessed 19th December 2015.

21 Optimus Solutions. The Advantages and Disadvantages or eLearning. URL: http://www.optimussourcing.com/learninghintsandtips/the-advantages-anddisadvantagesof-elearning Accessed 19th December 2015. 


\section{3. Розвиток системи електронного навчання в Київському національному університеті імені Тараса Шевченка}

Розроблення програмного забезпечення було розпочато в 2005-2006 роках. Перша версія програмної системи SMPR-06, представлена на конференції МеЛ-2006, була розроблена як набір окремих програмних модулів, що реалізують деякі алгоритми для розв'язування задач теорії прийняття рішень (ТПР $)^{22}$. Програмні модулі (розроблені студентами на лабораторних заняттях) функціонували незалежно, реалізовувалися різними мовами програмування та мали довільну структуру та візуальні інтерфейси.

Версія системи SMPR-08 надала можливість взаємодії модулів шляхом формування єдиних вимог до їхнього програмного забезпечення, реалізованого в мові програмування С\# за допомогою платформи .NET, інструментом розробки MS Visual Studio та технологією для командної розробки SVN. Понад 50 студентів брали участь у розробці всіх версій SMPR. Систему SMPR-08 можна назвати «навчально-методичною та демонстраційно-тестувальною» через іiі функціональний зміст. Поряд із демонстрацією конкретного рішення завдання користувач SMPR може перевірити рішення задачі та отримати оцінку «правильно» чи «неправильно».

Функція оцінювання знань студентів реалізується в SMPR-10 (представлена в МеЛ-2010, Київ, 2010), вдосконалюється інтерфейс системи, особливо за використання мов опису - української, російської, англійської та китайської (окремі модулі). SMPR-10 застосовується у низці вищих навчальних закладів України (зокрема, в Києві, Одесі, Ужгороді, Черкасах, Чернігові та інших) як підтримка навчальних курсів 3 теорії прийняття рішень 3 використанням навчальних посібників ${ }^{23}$.

Версія SMPR-12 може розглядатися як «комерційна» версія системи. Порівняно з SMPR-10, до SMPR-12 було додано дві основні функції: 1) оцінювання знань студента за всім курсом ТПР, виведення в «чіткій» або «нечіткій» формі; 2) друга функція пов'язана із захистом системи від несанкціонованого використання.

Загальна інформація про програмну систему SMPR така. Система складається з ядра та набору спеціалізованих модулів, які відповідають

22 Voloshyn A., Kovalev D. Educational and methodical testiruyusche-evaluator software system to support courses in decision theory. Problems of Computer Intellectualization, ITHEA, 2012. P. 293-298 (in Russian).

${ }^{23}$ Voloshyn O., Kovaliov D. Using e-learning tools during the "Decision Making Theory" course. SMPR system. Scientific Development and Achievements. 2018, vol. 5, pp. 379-390. 
за вирішення певних завдань класу. Ядро створює функціональне середовище модулів 3 можливістю паралельного вирішення завдань та обміну даними між модулями. Він складається із загальних інтерфейсів, стандартів обміну даними, системи підвищення та інформаційних систем про модуль.

\section{ВИСНОВКИ}

Розвиток дуже великих комп’ютерів та доступних для користувачів громади за рахунок існування цих розробок створює багатий навчальний контент та глобальне явище, в якому інформаційнокомунікаційні технології (ІКТ) використовуються для трансформації освіти. Освіті для свого розвитку потрібен засіб, що використовується для поділу матеріалу, спілкування від викладачів до учнів, які викладаються. Це будь-який із цих засобів масової інформації у формі електронного навчання. У впровадженні системи електронного навчання дизайн вимагає хорошого і швидкого, так що опосередковано підтримує продуктивність системи. Тому виникла потреба в переробці систем освіти, які використовуються для кращого задоволення цих потреб. Поява комп'ютерних технологій 3 передовим програмним забезпеченням дозволила вирішити багато складних проблем дуже швидко і $з$ меншими витратами. У цьому документі представлено характеристики поточного електронного навчання, а потім проаналізовано концепцію хмарних обчислень та архітектури хмарних обчислень, які описані шляхом поєднання особливостей електронного навчання 3 модельною архітектурою орієнтації на обслуговування (SOA). У процесі розроблення потрібна модель хмарних обчислень та SOA, яка надалі перетворилася в архітектуру орієнтації хмарних обчислень. За допомогою цих Моделей система може мати хороші та швидкі показники.

Сервісно-орієнтована архітектура (SOA) - це сукупність послуг, які спілкуються між собою для виконання певного бізнес-процесу. Ця парадигма передає дані між споживачами послуг та постачальником послуг просто чи складно. SOA - популярна стратегія для забезпечення інтегрованого, гнучкого та економічно ефективного (веб) сервісного підприємства. Це обіцяє сумісність, повторне використання, вільне сполучення та незалежність протоколу від сервісів як основних принципів SOA. Зазвичай цей стандартний підхід використовує вебсервіси як будівельний блок для підтримки конкретних бізнес-завдань. Веб-сервіси публікуються за допомогою інтерфейсу мови опису вебслужб (WSDL) і використовують простий протокол доступу до об'єктів (SOAP) як протокол зв'язку. На малюнку 1 показана операція, яку може 
виконувати кожен компонент ${ }^{24}$. SOA спонукає нас розуміти це як архітектуру, яка орієнтується на послуги. Послуги - це дискретні фрагменти програмного забезпечення, реалізовані 3 використанням чітко визначених стандартів та специфікацій інтерфейсу. Після розроблення та тестування сервіс подається до каталогу о r реєстр, щоб він був доступний іншим розробникам. Реєстр також містить репозиторій, який містить детальну інформацію про опубліковану службу, наприклад, як побудувати інтерфейс, які очікувані рівні обслуговування, як підтримувати повноваження тощо. Типовий SOA виглядатиме як на рис. $3^{25}$.

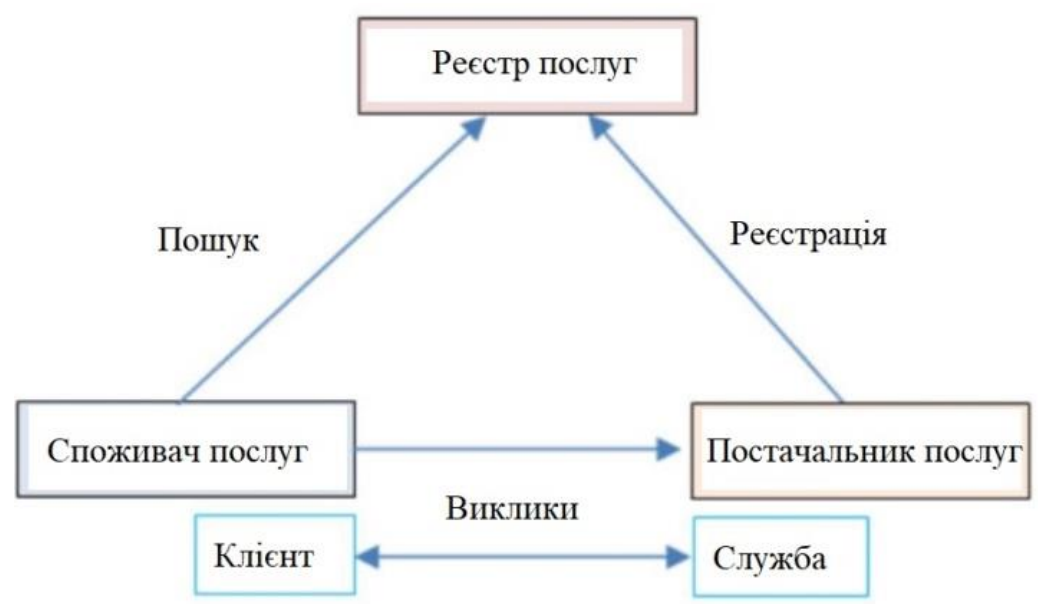

Рис. 3. Типовий SOA

Великий потенціал для розвитку електронного навчання мають хмарні обчислення. Хмарні обчислення - це обчислювальна модель, заснована на мережах, особливо на базі Інтернету, завданням якої $€$ забезпечення того, щоб користувачі могли просто використовувати обчислювальні ресурси на вимогу і платити гроші відповідно до

${ }^{24}$ Erick Fernando, Hetty Rohayani. AH, Pandapotan Siagian, Derist Touriano," Analysis of Security and Performance Service in Service Oriented Architecture (SOA) and Data Integration", International Conference On Electrical Engineering, Computer Science And Informatics, Agustus, 2014.

${ }^{25}$ Palanivel K., Kuppuswami S., Architecture Solutions to E-Learning Systems Using ServiceOriented Cloud Computing Reference Architecture. International Journal of Application or Innovation in Engineering \& Management (IJAIEM). March 2014. Volume 3, Issue 3, ISSN 2319-4847. 
їхнього використання за схемою вимірювання, подібною до споживання води та електроенергії. Тому вона пропонує нову бізнесмодель, коли послуги, які вона надає, стають обчислювальними ресурсами $^{26}$. Хмарні обчислення $є$ масштабованими та створюють віртуалізовані ресурси, які можна зробити доступними для користувачів. Користувачі не потребують спеціальних знань про концепцію хмарних обчислень для підключення своїх комп'ютерів до сервера, де встановлені програми та їх використання. Користувачі можуть спілкуватися через Інтернет 3 віддаленими серверами. Ці сервери можуть самі обмінюватися своїми обчислювальними слотами ${ }^{27}$. Хмарні обчислення - одна 3 нових тенденції технології, які, ймовірно, матимуть істотний вплив на середовище викладання та навчання $^{28}$.

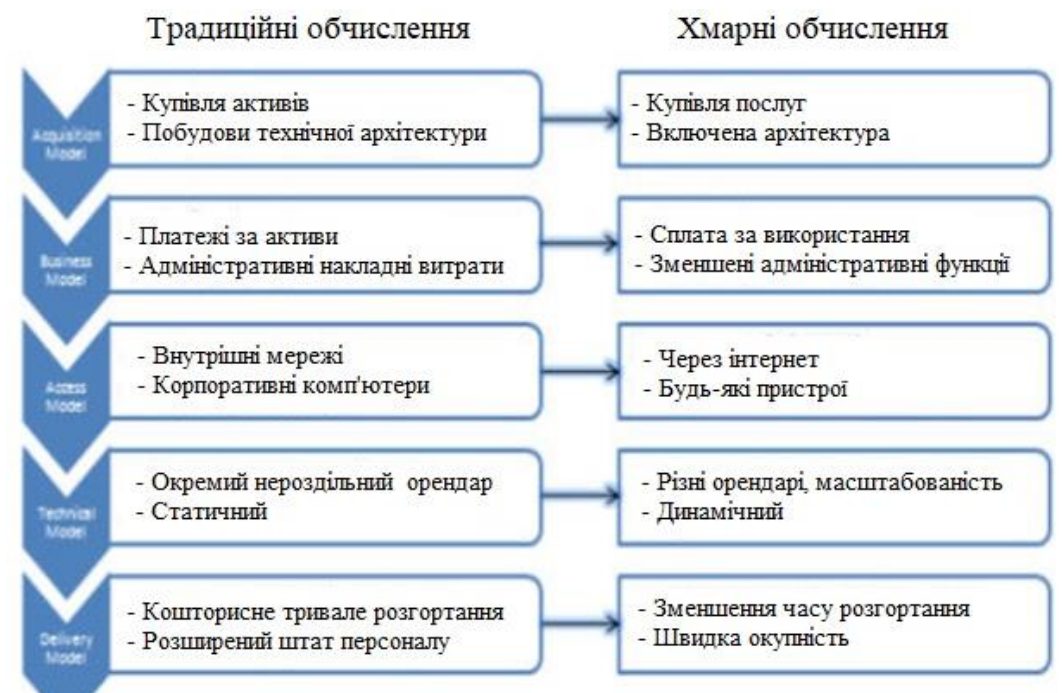

Рис. 4. Традиційні обчислення та хмарні обчислення

Сервісно-орієнтована архітектура хмарних обчислень (SOCCA) - це інша архітектура, запропонована дослідниками. Це теоретична архітектура, яка не реалізована, а обумовлена в роботі. Ця архітектура

${ }^{26}$ Chengyun Z. Cloud Security: The security risks of cloud computing, models and strategies. Programmer. pp. 71-73.

${ }^{27}$ Hayes B. Cloud computing. Comm. Acm, vol. 51, no.7, pp. 9-11, 2008.

${ }^{28}$ Tuncay E. Effective use of Cloud computing in educational institutions. Procedia Social Behavioral Sciences. P. 938-942, 2010. 
багато в чому схожа на ССОА і відрізняється від інших. Це ще одна архітектура, яка намагається скористатися цілями та поглядами SOA.

\section{АНОТАЦІЯ}

За умови розвитку сучасних технологій та зміни соціальних норм щодо відношення до навчання дуже важливою темою стає електронна освіта. Такий тип освіти виник близько 1980 p., але розвиток i розповсюдження засобів електронної освіти припали на початок XXI сторіччя. Сьогодні існують уже десятки успішних e-learning систем, що використовуються як в університетах, так й індивідуально. Важливою рисою створення таких систем $є$ звернення до алгоритмічних або інфраструктурних засобів комп'ютерних технологій. Завдяки модульності та підтримці комп'ютерних засобів запровадити часткове або повне дистанційне навчання (що також $\epsilon$ частиною e-learning) має можливість кожен, хто має відношення до освіти. Але варто мати на увазі, що засоби e-lerning вимагають від постачальників освіти інших підходів до мотивації студентів та подачі матеріалу, ніж звичайні. Проте використання таких засобів може значно збільшити аудиторію та якість самої освіти.

\section{ЛITEPATУPA}

1. Moore J.L., Dickson-Deane C., Galyen K. (2011). e-Learning, online learning, and distance learning environments: Are they the same? ScienceDirect. 1-4.

2. Gros B., García-Peñalvo F.J. (2016). Future trends in the design strategies and technological affordances of e-learning. In M. Spector B.B. Lockee \& M.D. Childress (Eds.), Learning, Design, and Technology. An International Compendium of Theory, Research, Practice, and Policy (pp. 1-23). Switzerland : Springer International Publishing. DOI:10.1007/978-3-319-17727-4_67-1

3. Sangra A., Vlachopoulos D., Cabrera N. (2012). Building an Inclusive Definition of E-Learning: An Approach to the Conceptual Framework. IRRODL.

4. Horton W.K. (2001). Leading E-Learning. Alexandria, VA: ASTD.

5. Rouse M. (2011, March). computer-based training (CBT). URL: www.whatis.techtarget.com/:http://whatis.techtarget.com/definition/compute r-based-training-CBT

6. Shimura K. (2006). Computer-based learning and web-based training: A review for Computer-based learning and web-based training: A review for. 59-63.

7. Dean C., Whitlock Q. (1992). A handbook of computer-based training. Based Training. New York : Nichols Publishing Company. 
8. Cross J. (2004). An informal history of eLearning. Emerald. 1-8.

9. Moore J.L., Dickson-Deane C., Galyen K. (2011). e-Learning, online learning, and distance learning environments: Are they the same? ScienceDirect. 1-4.

10. Sheridan D., Gardner L., White D. Cecil: The first web-based LMS. Proceedings of ASCILITE. Auckland, 2002.

11. URL: https://eliterate.us/state-higher-ed-lms-market-us-canada-fall2017-edition/

12. Brooks D.C. (2015). ECAR study of faculty and information technology, 2016. Research report. Louisville, CO: ECAR. URL: https://library.educause.edu/resources/2015/8/2015-student-and-facultytechnologyresearch-studies

13. Legon R., Garrett R. (2017). The changing landscape of online education (CHLOE): Quality Matters and Eduventures survey of chief online officers. 2017. URL: https://www.qualitymatters.org/node/1040

14. Youssef Y. Gamification in e-learning//2015. URL: https://www.researchgate.net/publication/301202645

15. Meltem Huri Baturay. An overview of the world of MOOCs//Procedia - Social and Behavioral Sciences. 2015. 174. 427-433.

16. Guragain N. E-Learning Benefits and Applications - Helsinki Metropolia University of Applied Sciences, Bachelor of Engineering//Information Technology. Thesis. February 2016. URL: https://core.ac.uk/download/pdf/38134334.pdf

17.E-learning Essentials, WorldWideLearn. URL: http://www.worldwidelearn.com/elearning-essentials/elearning-types.htm Accessed 9th December 2015

18. Kuhlmann T (2010). Why E-learning is so effective. URL: http://blogs.articulate.com/rapid-elearning/why-e-learning-is-so-effective/ Accessed 19th December 2015

19. Benefits of E-learning, WorldWideLearn. URL: http://www.worldwidelearn.com/elearning-essentials/elearningbenefits.htm

20. Mobbs R (2003). Disadvantages of E-learning, What is e-learning. URL:

https://www.le.ac.uk/users/rjm1/etutor/elearning/disadvofelearning.html

21. Optimus Solutions. The Advantages and Disadvantages or eLearning. URL: $\quad$ http://www.optimussourcing.com/learninghintsandtips/theadvantages-anddisadvantages-of-elearning Accessed 19th December 2015

22. Voloshyn A. Kovalev D. Educational and methodical testiruyuscheevaluator software system to support courses in decision theory, Problems of Computer Intellectualization, ITHEA. 2012. P. 293-298. 
23. Voloshyn O., Kovaliov D. Using e-learning tools during the "Decision Making Theory" course. SMPR system, Scientific Development and Achievements. 2018. Vol. 5. P. 379-390.

24. Erick Fernando, Hetty Rohayani. AH, Pandapotan Siagian, Derist Touriano," Analysis of Security and Performance Service in Service Oriented Architecture (SOA) and Data Integration", International Conference On Electrical Engineering, Computer Science And Informatics, Agustus, 2014.

25. Palanivel K., Kuppuswami S. Architecture Solutions to E-Learning Systems Using ServiceOriented Cloud Computing Reference Architecture, International Journal of Application or Innovation in Engineering \& Management (IJAIEM). 2014. March. Vol. 3. Issue 3. ISSN 2319-4847.

26. Chengyun Z. Cloud Security: The security risks of cloud computing, models and strategies. Programmer. 2010. May. P. 71-73.

27. Hayes B. Cloud computing. Comm. Acm. 2008. Vol. 51. № 7. P. 9-11.

28. Tuncay E. Effective use of Cloud computing in educational institutions. Procedia Social Behavioral Sciences. 2010. P. 938-942.

\section{Information about the authors: \\ Kovaliov D. I.,}

Postgraduate at Faculty of Computer Science and Cybernetics of Taras Shevchenko National University of Kyiv 4d, Akademika Hlushkova ave., Kyiv, 03680, Ukraine Voloshyn O. F., Professor at Faculty of Computer Science and Cybernetics of Taras Shevchenko National University of Kyiv 4d, Akademika Hlushkova ave., Kyiv, 03680, Ukraine 